\title{
The Reward and Punishment of the Civil Servants Apparatus In the Civil Service Police Unit and Wilayatul Hisbah Bener Meriah Regency
}

\author{
Fadhlon Saputra*1 Muhammad Bin Abubakar ${ }^{2}$ \& M. Akmal ${ }^{2}$ \\ 1Student of the Master Program of Public Administration, Universitas Malikussaleh, Aceh Utara, Indonesia \\ 2Master Program of Public Administration, Universitas Malikussaleh, Aceh Utara, Indonesia \\ *Corresponding Author: fadhlonsaputra@gmail.com
}

\begin{abstract}
This study examines the provision of rewards and punishments to ASN. The research objective was to understand how the process and impact of reward and punishment for ASN in Satpol PP and WH Bener Meriah Regency. The theoretical perspective used is the theory of public organizations, reward, and punishment, and the state civil apparatus. The research method used is qualitative. The results showed that the process of giving rewards and punishments was carried out in three stages: ASN inventory, priority scale creation, and decision making. The positive impact of giving rewards and punishments for ASNs in the Satpol PP and WH Office of Bener Meriah Regency is to increase work motivation and can help develop careers for ASNs. Whereas punishment has a positive impact on ASNs as a deterrent effect from repeating violations of duty and can improve their behavior at work which is then able to improve their performance in the future. The negative impact did not change the attitude/behavior of ASNs who were given punishment because they were annoyed at getting punished, or it could be said that ASN was not deterred by the actions of giving punishment by the leaders of Satpol PP and WH in Bener Meriah Regency.
\end{abstract}

Keywords: reward, punishment, asn

\section{Introduction}

Bureaucratic Reform is a strategic step to build the state apparatus so that it can be efficient and effective in carrying out general tasks of government and national development by taking steps that are fundamental, comprehensive, and systematic as an effort to improve and improve performance1. Based on the aforementioned view, Bureaucratic Reform is a government effort to build an efficient and effective apparatus which is one of the national discipline change programs so that the state civil apparatus has a productive work mentality and is competent in any given job responsibilities.

The definition of reward or reward is "a reward given to motivate employees or employees to be highly productive". For the definition of "Punishment is a threat of punishment which aims to improve the offending employees, maintain the applicable regulations, and provide lessons to the offender". The purpose of giving punishment is so that employees who violate it feel deterred and will not repeat it.

Through the role of the organization in the achievement of implementing rewards and punishments to create employee work motivation as the goals and objectives of the organization, while motivation is known as a process that determines the intensity, direction, and persistence of individuals in achieving goals.

The phenomenon of problematic employees and problematic employees is a routine thing that occurs in an organization that is different only in degree and frequency. Starting from mild to severe conditions, diligent or lazy, Satpol PP and Wilayatul Hisbah members in Bener Meriah Regency get the same rights.

The formulation of strategies and policies for human resources is carried out personally, therefore the solutions also use organizational channels. Given the importance of human resources which include the role, management, and utilization of the apparatus, it is necessary to spur employee morale to improve organizational performance.

The transformation process of the Satpol PP and Wilayatul Hisbah of Bener Meriah Regency is rolling following the development of the special status of Aceh Province, namely as a Province that applies Islamic law. As the intention of an organization that functions to ensure a sense of security in the community, of course, the Satpol PP and Wilayatul Hisbah of Bener Meriah Regency must be supported by human resources who can realize the vision and mission of Satpol PP and Wilayatul Hisbah of Bener Meriah 
Regency. In addition to human resources, of course, a human resource management system must also be built, the goal of which is to ensure the performance of the Satpol PP and WH of Bener Meriah Regency can improve according to what is expected both from internal (leadership) and external parties (the community).

The award program is running well. Since 2017 there have been 7 people receiving awards in various forms of awards. While the leadership is also very strict in enforcing disciplinary penalties for employees who are not disciplined and have committed violations, even in 20192 people were fired for committing violations. realization of performance achievements for 3 (three) years. Although the leadership has given rewards and disciplinary penalties, the target for achieving organizational performance has not been maximally achieved. However, when viewed in-depth, there is an increasing trend in performance achievements from year to year.

Enforcement of the reward and punishment system is one of the concerns of bureaucratic reform in the field of apparatus resources which has been widely practiced at both the central and regional levels. This system accommodates rewards in the form of incentives for government employees who show good performance and penalties for government employees who violate the rules. This system is mostly implemented in local government circles and is usually provided in the form of monetary incentives. Giving rewards and punishments does not always run effectively and efficiently as expected. As the results of initial observations of researchers at Satpol PP and WH Bener Meriah Regency, the implementation of reward and punishment is still not effective. So that researchers are interested in researching the Rewards and Punishment of State Civil Servants in the Civil Service Police Unit and Wilayatul Hisbah, Bener Meriah Regency.

\section{Formulation of the problem}

1. What is the process of giving rewards and punishments to state civil servants in Satpol PP and WH Bener Meriah Regency?.

2. What is the impact of giving rewards and punishments to state civil servants in Satpol PP and WH Bener Meriah Regency?.

\section{Literature Review}

Theory is a very important foundation in understanding, interpreting and interpreting data, therefore to facilitate the interpretation of the data in this study, the authors use several theories as follows:

\section{Public Organizations}

Sulistyani (2009: 55) views public organizations as government agencies that have formal legality, facilitated by the state to carry out the interests of the people in all complex fields. In addition, according to the researcher's review of Mahmudi's (2011) explanation, it can be seen that Mahmudi views public organizations as agencies that have the goal of providing services to the community and creating social welfare. which organizes the needs of the community facilitated by the government.

\section{The Reward And Punishment}

The reward is a reward, reward, reward, or reward. Awards or prizes are given for something done well and right. The reward is a result given as a reward for doing something good, right, and satisfying. Etymologically, the origin of the word sanction is ganjar which means giving a gift or wage. From this understanding, reward is a pleasant treatment as a reward for good deeds received by someone ('amal alshalih) or success in achieving the best achievement (Al-Rasyidin, 2008, p. 93). According to Sardiman (2014, p. 46).

Punishment is a reward for doing something that violates certain rules. Punishment is given to create order and comfort while studying. Teaching and learning activities will run conducive if students comply with the applicable regulations while learning takes place. Etymologically, punishment means sanctions, imposed on people who break the law. So, punishment is basically an unpleasant act given to someone in return for a mistake or bad deed ('amal al-syai'ah) that has been done (Al-Rasyidin, 2008, p. 98).

\section{State Civil Apparatus}

After the issuance of Law No. 5/2014 on Civil Apparatus, the designation of government employees who were formerly PNS (Civil Servants) has changed to State Civil Servants, abbreviated as ASN. Previously, provisions regarding government employees were regulated in Law Number 43 of 1999 concerning Amendments to Law Number 8 of 1974 concerning Civil Service Principles. In this regulation, it is stated that civil servants are one of the state administration facilities that are appointed and paid by the government to carry out certain state tasks based on regulations that have been made and established by the state. Civil servants as state servants and public servants have the responsibility to carry out their respective 
duties (Hartini. 2002: 32).

The State Civil Apparatus in charge of the Regional Government is the human resources in charge of implementing the wheels of government and serving the community. The civilian apparatus of the State is tasked with carrying out government administration in the regions and receiving compensation (salaries) based on the stipulated laws and regulations with the following conditions: a) Fulfilling the specified conditions b) Appointed by an authorized official, c) Assigned with duties in a public office, and d) Paid according to statutory regulations. In carrying out its duties, the State Civil Apparatus has obligations that must be obeyed, namely: a) Must be loyal and obedient to Pancasila, the 1945 Constitution, the State, and the Government, and must maintain the unity and integrity of the nation in the Unitary State of the Republic of Indonesia (Article 4). b) Must comply with all applicable laws and regulations and carry out official duties entrusted to him with full devotion, awareness, and responsibility (Article 5). c) It is obligatory to keep a secret of position and can only reveal the secret of the position to and on the order of an authorized official at the power of law (Article 6) (ASN Law).

\section{Methods}

This study uses qualitative research with a descriptive analysis approach, because the problem is very comprehensive, in-depth and very broad. Data collection was carried out by observation, interviews and documentation.

\section{Results and Discussion}

The process of giving rewards and punishments to state civil servants in the Satpol PP and WH Services of Bener Meriah Regency is carried out in three stages, namely through ASN inventory, making priority scales, and making decisions by the leadership in providing rewards and punishments for ASN.

Based on the research results, it is known that in the ASN inventory indicator there are 214 human resources consisting of 18 ASN people and the rest are non-civil servants staff. It is also known that out of 18 ASNs who served in Satpol PP and WH in Bener Meriah Regency in three years, only 7 received rewards, and for three years there were 5 people who received punishment.

Based on the results of the research, it is known that to get rewards, ASNs must have the criteria as stated in article 83 of Law Number 4 of 2014 concerning State Civil Apparatus which states that ASNs who have shown loyalty, devotion, proficiency, honesty, discipline, and work performance in carrying out their duties can be rewarded. Meanwhile, to give punishment to ASN refers to Government Regulation Number 53 concerning Discipline of State Civil Apparatus. The punishment was given to ASN who violated their discipline on duty.

In the priority scale indicator, it is known that what should be the priority scale for Satpol PP and WH of Bener Meriah Regency in providing rewards and punishments is the formation of Standard Operating Procedures (SOP) which until now has not been owned. So that the indicators of reward and punishment are not firm and do not match the needs of the agency. So far, ASN assessments for getting rewards are assessed from the individual performance index attached to the employee performance targets, while punishment is assessed from violations committed while on duty.

The absence of SOP for reward and punishment in Satpol PP and WH in Bener Meriah Regency makes ASNs indifferent and does not care about improving work performance and influencing their work motivation, they consider the unclear assessment indicators of ASN which get reward and punishment are not firm so there is no need to bother to improve work performance.

The process of giving rewards and punishments should involve an appraisal team consisting of leaders and other fields to provide an assessment in giving rewards and punishments, but based on the results of the research it is known that those who give judgments and decisions are leaders, light punishments and are being given verbal and written warnings. whereas if ASN commits a serious violation, it will be given the delegation of authority to punish the Bener Meriah District Education and Training Personnel Board as the related agency which has the authority to give punishment in the severe category to ASN.

Based on the results of the study it can be concluded that the process of giving rewards and punishments in Satpol PP and WH Bener Meriah Regency is still not as effective and efficient as expected because no SOP regulates the giving of rewards and punishments to ASNs in Satpol PP and WH Bener Meriah Regency, thus making ASN does not try to increase its work motivation to get rewards. Likewise, ASN is subject to punishment because the absence of SOP makes ASN not deterred from the punishment given, especially if it only gets punishment in the form of verbal and written warnings.

Based on the results of the study, it is known that there are two types of impacts of giving rewards and punishments to ASNs in Satpol PP and WH Bener Meriah Regency, namely positive impacts and negative impacts. The impact of giving rewards and punishments arises as a result of the correct application of the targets to be achieved, 
The results showed that the positive impact of giving rewards is to increase work motivation and can help career development for ASNs. Whereas punishment has a positive impact on ASNs as a deterrent effect from repeating violations of duty and can improve their behavior at work which is then able to improve their performance in the future.

Another positive impact is that the provision of rewards and punishments can spur an increase in performance and work performance for other ASNs, and minimize the occurrence of violations in suspicion by ASNs when they know the punishment given to their friends who commit violations.

Based on the results of the study, it is known that the giving of rewards and punishments also has a negative impact, including in giving rewards due to the lack of desire to have more work performance, because the awards given are limited to certificates or placards, while ASN hopes to get rewards in the form of salary increases, promotions position, and other things that spur an increase in future work performance.

The negative impact of giving punishment is the unchanging attitude/behavior of ASNs who are given punishment because they are annoyed at getting punished, or it can be said that ASN is not deterred by the action of giving punishment by the leaders of Satpol PP and WH Bener Meriah Regency.

\section{Conclusions}

Based on the research results above, it can be concluded as follows:

1. The process of giving rewards and punishments to state civil servants in the Satpol PP and WH Services of Bener Meriah Regency is carried out in three stages, namely through ASN inventory, making priorities and decision making by the leadership in providing rewards and punishments for ASN.

2. The positive impact of giving rewards and punishments for ASNs in the Satpol PP and WH Office of Bener Meriah Regency is to increase work motivation and can assist career development for ASNs. Whereas punishment has a positive impact on ASNs as a deterrent effect from repeating violations of duty and can improve their behavior at work which is then able to improve their performance in the future.

3. The negative impact of giving rewards and punishments for ASNs in the Satpol PP and WH Services of Bener Meriah Regency is in giving rewards due to the lack of desire to have more work performance because the awards given are limited to certificates or placards, while ASN hopes to get rewards. in the form of salary increase allowances, promotion, and other things that will spur increased work performance in the future. The negative impact of giving punishment is the unchanging attitude/behavior of ASNs who are given punishment because they are annoyed at getting punished, or it can be said that ASN is not deterred by the action of giving punishment by the leaders of Satpol PP and WH Bener Meriah Regency.

\section{Recommendations}

1. It is hoped that the Satpol PP and WH of Bener Meriah Regency will immediately ratify the Standard Operating Procedure for giving rewards and punishments to ASN so that the process of giving rewards and punishments can run effectively and efficiently.

2. It is hoped that the Satpol PP and WH of Bener Meriah Regency will form a team of assessors and assessment indicators for giving rewards and punishments that are firm and clear for ASNs to minimize the negative impact of giving rewards and punishments.

\section{References}

Agus Dharma, (1995). Manajemen Prestasi Kerja. Jakarta : Rajawali

Al-Rasyidin. (2008). Falsafah Pendidikan Islam. Bandung: Cita Pustaka.

Dessler. (2000). Manajemen Sumber Daya Manusia, Edisi Terjemahan, Jakarta. Penerbit. PT. Prenhallindo.

Dessler. (2006). Manajemen Sumber Daya Manusia. Jakarta. PT. Indeks.

Dessler, G. (2007). Manajemen Sumber Daya Manusia Edisi Bahasa Indonesia Jilid 1. Jakarta : Prenhallindo.

Hani. (2008). Manajemen Personalia \& SDM.Yogyakarta :BPFE

Hasibuan, H.M. (2009). Manajemen Sumber Daya Manusia Edisi Revisi. Jakarta : PT.Bumi Aksara

Ilyas, Y. (1999). Kinerja : Teori Penilaian dan Penelitian. Jakarta: FKM UI. IQ. Jakarta: PT Gramedia Pustaka

Utama

Kadarisman, M. (2012). Manajemen Pengembangan Sumber Daya Manusia, Edisi. Pertama, Cetakan pertama, Rajawali Press, Jakarta,.

Mangkunegara, Anwar Prabu A.A. (2007). Evaluasi Kinerja Sumber Daya Manusia.Refika Aditama. Bandung Mangkuprawira, Tb. Sjafri. (2009). Horison Bisnis, Manajemen, dan Sumber Daya. Manusia. 
Siagian. (2008). Manajemen Sumber Daya Manusia. Jakarta : Bumi Aksara.

Siagian,Sondang, (2003), Manajemen Sumber Daya Manusia, Jakarta Bumi Aksara.

Undang-Undang Nomor 5 Tahun 2014 Tentang Aparatur Sipil Negara. 